\title{
A DEFESA NA EXCEÇ̃̃o DE PRÉ-EXECUTIVIDADE O CASO DA EXECUÇÃO JUDICIAL HIPOTECÁRIA - LEI N. 5.741/71
}

\author{
Vladimir Garcia Magalhães \\ Doutor em Direito Civil pela Faculdade de Direito da \\ Universidade de São Paulo \\ Leandro Knorre \\ Graduado pela Faculdade de Direito da Universidade \\ de São Paulo
}

\begin{abstract}
Resumo:
A doutrina vem lapidando a exceção de pré-executividade nas últimas décadas, para que, com base no princípio processual da liberalidade das formas, seja instrumento adequado à defesa do suposto devedor quando o exeqüente não possuir os requisitos necessários ao ajuizamento da execução, sem a necessidade de realização de penhora. A exceção de pré-executividade poderá tanto suscitar a nulidade da execução quanto possibilitar sua suspensão, respaldado no poder geral de cautela do juiz, perigo de dano irreparável a uma das partes.
\end{abstract}

\begin{abstract}
:
The doctrine has been lapidating the pre-executivity exception in the last decades, in order to be, based in the procedural principle of formal liberality, a suitable instrument to the delense of the supposed debtor when the execution creditor doesn't have the necessaries requirements to the execution's judgement, without the necessity of the allachment's realization. The preexecutivity exception could suscitate the nullity of the execution and make possible its suspension, smoothed down in the general power of the judger's caution, in danger of itreparable damang to one of the parts.
\end{abstract}

Unitermos: exceção de pré-executividade; ajuizamento dla execução; nulidade da exccução; exceção judicial hipotccária; Lci n. 5.74l/7!

1. Introdução.

1.1. A exceção de pré-cxecutividade.

A prcvisão legal para a chamada "exceção de pré-executividade" não pode ser encontrada expressamente no Código de Processo Civil, tampouco na legislação extravagante. Trata-se de criação doutrinária, aceita pacificamente pela Jurisprudência nacional, utilizada para, sem a necessidade de garantir o Juizo (usualmente seguro pela penhora de bens de valor equivalente ao do crédito ou pelo depósito desse montante), impedir o andamento de execução em determinadas situações, como, por exemplo, a 
nulidade do título executivo e, de maneira geral, falta de condições para a execução, se perceptível de plano.

Sua origem, da maneira que a conhecemos, é atribuída a Pontes de Miranda,' em parecer emitido para a Cia. Siderúrgica Manesmann, que, em 1966, foi vítima de uma série de execuções fundadas em títulos com assinaturas falsificadas. Registramos também outros três precedentes: o Decreto Imperial n. 9.885/1888² e o Decreto n. 848/1890, ${ }^{3}$ que regulavam a execução fïscal e permitiam a defesa do réu antes da penhora, apenas nos casos de quilação do débito ou anulação da dívida; e o Decreto do Estado do Rio Grande do Sul, de n. 5.225/32, ${ }^{4}$ que inseriu no Código de Processo Civil e Comercial do Estado a "exceção de imipropriedade do meio executivo" meio hábil também para suscitar suspeição e incompelência do Juízo.

Não são de se estranhar os registros de institutos similares à exceção de pré-executividade en momentos tão díspares. Explicamo-nos: o processo de execução, como o previsto pelo Código de Processo Civil de 1973, comporta uma notória (e antiga) lacuna em nosso ordenamento jurídico, frente aos princípios do contraditório e da ampla defesa atualmente insculpidos pela Carta Magna de 1988. A própria lógica jurídica, atemporal, conduz ao entendimento de que mesmo o processo de execuçãocom sua peculiar característica de servir à rápida satisfação do crédito exigido pelo portador de título dotado de força executiva por sua liquidez, certeza e exigibilidade deva prever a imediata extinção do feito que não cumpra seus requisitos essenciais e seus pressupostos processuais, submetendo-o ao reexame do julgador quando este não o perceber por si só.

1.2. O poder cautelar geral do juiz.

O livro III do CPC trata do processo cautelar, estando inserido nele o art. 798 do CPC, que analisaremos adiante como uma das fontes geradoras do poder cautelar geral do juiz. Ocorre que, para se discutir este poder acautelatório do magistrado no exercício da sua função administrativa no processo e jurisdicional, surge uma primeira e fundamental pergunta: o poder cautelar geral do juiz se limita a ser exercido, exclusivamente, no âmbito do processo cautelar, ou pode ser também exercido em

1. MIRANDA, Pontes de. “Parecer n. 95”, Dez anos de pareceres. Rio de Janciro: Francisco Alves, 1975, pp. 127-135, apud MOREIRA, Lenice Silveira. "A exceçāo de pré-executividade e o juízo de

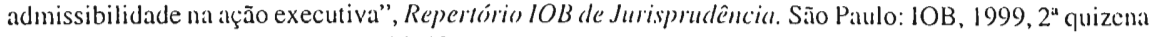
de fevereiro, n. 4, caderno 3, pp. 102-89.

2. BANDEIRA, Souza. Novo mamual dos feitos da Fazenda. Rio de Janeiro, ago/1888, nola 114 , apud SILVA, José Vilaço da. "Exceção de pré-executividade e a execução liscal" Revisıa de Esitudos" Tributários. Porto Alegre: Síntese, 2000, Ano II, n. 11, jan./fev., p. 15.

3. NETTO, Nelson Rodrigues; "Exceção de pré-executividade". Revisıa de Procesșo. São Paulo: RT, 1999, ano 24 , n. 95, jul./set., p. 33.

4. BOJUNGA, Luiz Edmundo Appel. "A exceção de pré-executividade", Révista de Processo. São Paulo: RT, 1989, ano .14, n. 5.5, jul./set., p. 67. 
decisão interlocutória, em qualquer dos outros gêneros de processo, quando surge a ameaça ao direito tutelado ou a ser tutelado naquela ação? Além disso, em caso afirmativo, impõe-se indagar: esta ameaça e um eventual provimento cautelar podem ser tratados como uma questão incidental?

Esta é exatamente a questão primordial na análise crítica do poder cautelar geral do juiz. Infelizmente, este aspecto não foi suficientemente discutido e analisado pela doutrina, o que enfatiza a necessidade de que isto seja feito neste trabalho. Demonstraremos, no decorrer dele, que o poder cautelar geral do juiz pode ser exercido no âmbito de qualquer tipo de processo e não-só no âmbito do processo cautelar.

\subsection{Objetivos.}

O presente artigo visa, mediante o exame da doutrina, da Jurisprudência e da legislação aplicável, delimitar o âmbito da delesa do devedor via exceção de préexecutividade, inclusive com base no exercício do poder geral de cautela do juiz, conceituá-lo, fundamentando-o legal, doutrinária e logicamente.

Visa também estudar sua aplicação, em específico, à execução hipotecária prevista pela Lei n. 5.741/71, pelo fato de esta, na prátical, ter-se apresentado como meio de execução excessivamente gravoso para o devedor, por prever a rápida imissão na posse, pelo credor, do imóvel hipotecado.

Procuraremos demonstrar, também, que havendo justa controvérsia quanto ao título que fundamenta a execução, ceifando-lhe a liquidez, certeza ou exigibilidade, o suposto devedor poderá, para resguardar-se do dano irreparável que o ameaça, opor a exceção de pré-executividade, trancando de pronto o processo de execução viciado, em defesa dos princípios constitucionais do devido processo legal (art. $5^{\circ}, \mathrm{LIV}$, da CF), do contraditório e da ampla delesa (art. $5^{\circ} \mathrm{LV}$, da CF) - e do direito à moradia (art. $6^{\circ}$ caput, da CF), no caso da execução hipotecália.

2. O Processo de Execução.

Princípios do processo executivo - requisitos para a execução - o caso específico da execução hipotecária prevista pela Lei n. 5.741/71.

Para melhor analisar a exceção de pré-executividade e sua aplicação, fazse necessária uma revisão do processo de execução, seu conceito, princípios e requisitos. Finalmente, faremos breve análise da controvertida execução hipotecária prevista para os fïnanciamentos vinculados ao Sistema Financeiro da Habitação, por ser o caso mais extremo de execúçã̃o excessivamente gravosa para o devedor de que temos notícia.

\subsection{Princípios:}

Os princípios, apesar de sua natural abstração, são de grạnde valia no trabalho responsável de interpretação de normas jurídicas. Francisco Amaral Neto 
esclarece que os princípios têm a função de fundamentar ou completar o sistema, constituindo a base do direito positivo ou orientando o intérprete no caso de insuficiência da lei ou do costume ${ }^{5}$. Assim, para ter uma visão sistêmica e não incorrer em interpretações míopes, deve-se procurar estudar os princípios que orientam nosso ordenamento jurídico, independentemente da nomenclatura e classifïcação que cada autor adota por razões didáticas.

a. Autonomia: o processo de execução não se confunde com o de conhecimento". A atividade cognitiva no processo de execução é extremamente restrita, sendo permitida de maneira ampla nos embargos de devedor, ação de conhecimento incidental ao processo de execução, apenas quando tiver fundamento em título extrajudicial, conforme o art. 745 do CPC. Quando se tratar de execução fundada em título judicial, o rol de matérias argüíveis nos embargos é muito menor (art. 74I do CPC). Essa restrição ao direito do contraditório se justifica apenas pela existência do princípio da titularidade.

b. Titularidade: a execução, para ser válida, deverá ser fundada emn título executivo líquido, certo, e exigível. Originalmente, toda a atividade executória era fundada no efeito executivo da condenação, realizada pelo juiz no âmbito de sua atividade jurisdicional $^{7}$ É comum haver necessidade de liquidação de sentença, que deve ser realizada antes de ajuizada a execução. Ao título extrajudicial somente será atribuída a mesma força executória por determinação legal, quando atender aos seus rigorosos requisitos. O exame de tais requisitos deverá ocorrer previamente à penhora (se visualizada sua inexeqüibilidade de plano), ou em sede de embargos de devedor (se necessária dilação probatória que não seja por prova pré-constituída), para que sejam obedecidos os princípios do contraditório e da ampla defesa.

c. Patrimonialidade: "o devedor responde [...] com todos os seus bens presentes e futuros" (art. 591 do CPC - grifamos), dado o caráter real da execução. Com a edição da Lex Poetelia Papiria, em 326 a.C., alastou-se do Direito Romano a responsabilidade pessoal do devedor, que deixou de responder pela dívida até com seu corpo, se fosse necessário. ${ }^{\circledR}$ Essa lei demonstra o avanço da civilização, mantido em todos os sistemas jurídicos derivados do Direito Romano. A exceção, em nosso ordenamento, é a prisão por dívida do responsável pela obrigação alimentícia e do depositário infiel, quando inadimplentes (art. $5^{\circ}$. LXVII, CF, e art. 733, § $1^{\circ}$ c 904, $\$$ único, do $\mathrm{CPC}$ ).

5. AMARAL NETO, Francisco. "Direito Constitucional: A eficácia do Código Civil Brasileiro após a Constituição", in Repensando o Direito, p. 32l, «pud VIANA, Rui Geraldo Camargo, "O direito à moradia", Revista da Faculdade de Direito. São Paulo: Faculdade de Direito da Universidade de São Paulo, 2000, v. 95, jan./dez., pp. 546-547.

6. ASSIS, Araken de, Manual do processo de execusāo, São Paulo: RT, 2000, 6 a ed., pp. 99-I00.

7. Ibidem.

8. DAL COL, Helder Martinez. "A objeção de não-executividade”, Reperturio IOB de Jurisprudência. São Paulo: IOB, 2000, Iª quizena de maio, n. 9, caderno 3, p. 201. 
d. Finalidade de satisfação do credor: "a norma pouco disfarça a ideologia do sistema executivo. O conjunto dos meios executivos [...] tem o único objetivo de satisfazer o credor"' (grifamos). Portanto, a execução alcança o patrimônio do devedor até o valor do crédito exigido. Limitado pelos princípios da patrimonialidade e da dignidade humana, é da satisfação do credor que se origina o princípio da especificidade e suas exceções (artigos 627,633 e 643 do CPC, nos casos de obrigação de entrega de coisa certa, de fazer, e de não fazer, respectivamente), e também os princípios da menor onerosidade, da utilidade e da disponibilidade.

e. Dignidade humana: "embora o processo de execução se apresente, aqui e ali, marcado de certo rigor para com o executado, a execução não pode ser catastrófica, utilizada como meio de levar o devedor à desgraça"lo (grifamos). O art. 649, que relaciona os bens absolutamente impenhoráveis, obedece a esse princípio. A esse respeito destacamos a Declaração Universal dos Direitos Humanos, realizada pela Assembléia Geral da Organização das Nações Unidas, em 10/12/48, da qual destacamos o trecho a seguir: (Art. 25, I) "Todo ser humano tem direito a um padrão de vida capaz de assegurar a si e a sua família saúde e bem-estar, inclusive alimentação, vestuário, habitação, cuidados médicos e os serviços sociais indispensáveis..."

f. Especificidade: sempre que possível, o credor receberá, pela via da execução, precisamente aquilo que obteria se a obrigação houvesse sido cumprida pontualmente

g. Menor onerosidade: a temperança deve orientar o processo executivo, conforme o caput do art. 620 do CPC: "Quando por vários meios o credor puder promover a execução, o juiz mandará que se faça pelo modo menos gravoso para o devedor."

h. Utilidade: a execução inútil ao credor não deve prosseguir (art. 659, § $2^{\circ}$, do CPC). "Execuşão que apenas cause prejuizo ao executado atenta contra a dignidade da Justiça"12

i. Disponibilidade: o credor pode desistir da execução, total ou parcialmente, quando bem entender. Entretanto, reforçando a autonomia do processo executivo em relação ao processo de conhecimento, o suposto devedor poderá, inclusive para evitar a futura execução do título, persistir nos embargos de devedor que versarem sobre questão de mérito.

\subsection{Requisitos para a execução.}

Genericamente, os requisitos para a validade de qualquer relação jurídica processual podem ser classificados em: condições da ação (art. 267, VI, do CPC: possibilidade jurílica, interesse de agir e legitimidade ad causam) e pressupostos

9. ASSIS, Araken de, op. cil.. p. 102.

10. MILHOMENS, Jônatas. Processo de Execuçũo. Rio de Janeiro: Forense, 1991, p. 83.

11. Conforme THEODORO JR., Humberto. Comentário. N. 17, p. 31, apud MILHOMENS, op. cit., p. 82.

12. MILHOMENS, Jônatas, ibidem. 
processuais (citação válida; representação adequada; inexistência de perempção, litispendência ou coisa julgada; petição inicial que não seja inepla; juízo competente etc; o art. 301 do CPC enumera hipóteses de inobservância dos pressupostos processuais).

Especificamente, a ação de execução requer a existência de tílulo executivo, seja judicial (oriundo de atividade jurisdicional) ou extrajudicial (previsto em lei, usualmente decorrente de contratos ou títulos de crédito em geral). Para que o título seja verdadeiramente executivo deverá apresentar-se na forma escrita ${ }^{13}$ 'e representar obrigação certa, líquida e exigível (art. 586 do CPC). Em caso contrário, a execução será nula (art. 618, I, do CPC).

Conceito clássico nos ensina Calamandrei, de que há certeza do crédito quando não existe controvérsia sobre sua existência (an debeatur); liquidez, quando é determinada a importância exata da prestação (quantum debeatur); c exigibilidade; quando o.seu pagamento não depende de lermo ou condição, nem está sujeito a outras limitações. ${ }^{14}$

\subsection{Certeza e liquidez.}

Para admitir a execução, o juiz deverá, primeiramente, mediante exame sumário do título executivo, atestar a existência da obrigação. Para tanto, deverá verificálo do ponto de vista da forma do título e da substância da obrigação nele representada, quanto aos seus sujeitos ativo e passivo, e quanto à natureza da mesma: Nada impede, no entanto; que o devedor ulteriormente comprove a inexeqüibilidade do título, devendo então ser extinta a execuçã̃o, fulminada pela nulidade.

Por lorça do disposto no all. 1.533 do Código Civil, trazemos jungidos os conceitos de liquidez e certeza: "Considera-se líquida a obirigação certa, qutanto à sua existência, e determinada, quanto ao seu objeto."

Não se deve, contudo, realizar uma interpretação literal de tal dispositivo. A Doutrina e a Jurisprudência ${ }^{15}$ nacionais, ern apatente unanimidade, entendem líquida a obrigação deteminável mediante simples cálculos aritméticos. Vejamos:

13. DINAMARCO, Cândido Rangel. Execusão Civil. São Paulo: Malheiros, 2000, $7^{\text {a }}$ ed., pp). 483485. No mesmo sentido: THEODORO JR:, Humberto. Curso de Dircito Processiual Civil. Rio de Janeiro: Forense, 1999, $26^{\mathrm{a}}$ ed., v. 1I, p. 34.

14. CALAMAND́REI, “El Procedimiento Monitorio”, p. 104, trad. Sentís Melendo, ayud VILLAR, Willard de Castro, Processo de Execusão, São Paulo: RT, 1975, p. 175.

15. REsp. 4.486, 3" Turma do STJ, Rel. o Exmo. Sr. Min. Cláudio Sintos, DJ de 22/10/90, p. II 665; REsp. 32.176, 4a Turma do STJ, Rel. o Exmo. Sr: Min. Ruy Rosado de Aguiar, DJ de 15/(08/94, p. 20.337;

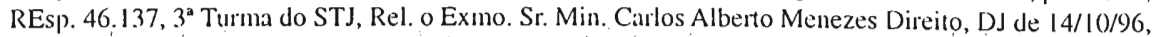
p. 38.999; REsp. n. I I.373-MG, 4 a Turma do STJ, Rèl. o Exmo. Sr. Min. Sálvio de Figueiredo Teixeira, unânime, publicado no DJU de 09/03/92, p. 2585; na JBCC, v. 166, p. 253; na LEXSTJ, v. 37, p. 1.56; na REVPRO, v. 66, p. 242; e na RSTJ, v. 34, p. 346; REsp. n. 29.661-MG, 4 a Tuma do STJ, Rel. o Exmo. Sr. Min. Ruy Rosado de Aguiar, unânime, publicado no DJU de 27/(06/94, p. 16984; REsp. n. 61776-RS, $3^{\text {* }}$ 
"Constitui judicioso entendimento dominante o de que a liqüidez do crédito se contenta com a deterninabilidade do 'quantum debeatur' não sendo necessário que o título se refira, desde logo, a um montante determinado. O que importa é que o título executivo forneça todos os elementos imprescidiveis para que, mediante simples operação aritmética e aplicação da lei, possa ser encontrado o mímero de unidades (na maior parte dos casos, unidades de moeda), pelo qual a execução se fará: sendo necessário buscar elementos "aliunde"l', faltará o requisito da liqüidez". (DINAMARCO, Cândido Rangel, op. cit., pp. 494-495 - grifamos). ${ }^{17}$

Por isso é que determinados títulos, como é o caso, por exemplo, dos contratos de abertura de crédito, devem ser acompanhados do extrato demonstrativo do crédito efetivamente utilizado para demonstrar sua liquidez. No entanto, a aceitação de documento elaborado unilateralmente, como prova da liquidez de contrato de abertura de crédito, já foi objeto de divergência entre a $3^{3}$ e a $4^{a}$ Turma do STJ ${ }^{18}$ Atualmente, a Súmula 233 do STJ trata do assunto: "O contrato de abertura de crédito, ainda que acompanhado de extrato da conta-corrente, não é título executivo" ensejando, no entanto, o ajuizamento de ação monitória (conforme a Súmula 247 do STJ).

Situação peculiar é a da ação declaratória, proposta anteriormente à execução, na qual se discute a legalidade do débito representado no título, quanto à sua existência e ao seu montante. Alguns autores entendem que a execução deva prosseguir, pela incidência, na espécie, do art. $585, \$ 1^{\circ}$, do CPC: “A propositura de qualquer ação

Turına do STJ, Rel. o Exıno. Sr. Min. Carlos Alberto Menezes Direito, unânime, publicado no DJU de 14/ 04/97, p. 12736; REsp. n. 150.021- MG, $3^{3}$ Turma do STJ, ReJ. o Exmo. Sr. Min. Waldemar Zveiter, unânime, publicado no DJU de 19/04/99, p. 135 e na JSTJ, v. 6, p. 24I; REsp. n. 152.426, $1^{\text {a }}$ Turma do STJ, Rel. o Exıno. Sr. Min. Demócrito Reinaldo, unânime, publicado no DJU de 07/12/98, p. 42 e na

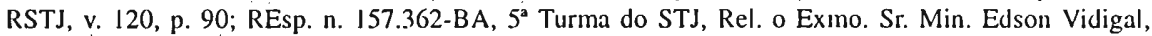
unânime, publicado no DJU de 29/03/99, p. 201; REsp. n. 195.248-SC, $3^{\text {a } T u r m a ~ d o ~ S T J, ~ R e l . ~ o ~ E x ı m o . ~ S r . ~}$ Min. Eduardo Ribeiro, unânime, publicado no DJU de 28/08/2000, p. 76; Agravo regimental no agravo

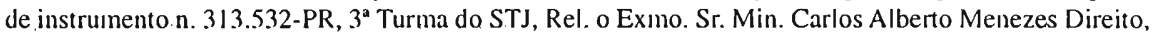
unânime, publicado no DJU de 09/04/2001, p. 358; REsp. n. 270.674-RS, 3ª Turma do STJ, Rel. o Exmo. Sr. Min. Carlos Alberto Menezes Direito, unânime, publicado no DJU Je 30/05/2001, p. 46.3; REsp. n.

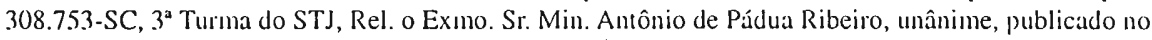
DJU de $11 / 06 / 200)$, p. 210.

16. Em outro lugar; de outra fonte.

17. Neste sentido: VILLAR, Willard de Castro, op. cit., p. 176; ASSIS, Araken de, op. cit.., pp. 131132; SILVA, Antônio Carlos Costa e. Da jurisdiçũo executiva e dos pressupostos da execuf̧ão civil. Rio de Janeiro: Forense, 1980, p. I54; THEODORO JR., Humberto. Processo de Execuçũo. São Paulo: LEUD, 1975, p. 102; ZAVASCKI, Teori Albino, Títuló Executivo e Liquiduşão. São Paulo: RT, 1999, p. 143. Com outras palavras: GRECO, Leonardo. O Processo de Execuçūo. Rio de Janeiro: Renovar, 2001, v. II, p. 181.

18. Conforme THEODORO JR., Humberto. "Contrato de abertura de crédito como título executivo", Revista Forense. Rio de Janeiro: 1996, ano 92, v. 334, abr./jun., p. 231. Conforme o mesmo autor, a $4^{\mathrm{a}}$ Turma do STJ manifestou-se a favor nos seguintes casos: REsp. n. 36.803-0/SP, DJ de 1 I/10/93; REsp. n. 46.251-7/DF, DJ de 19/I2/94; e REsp. n. 66.18I - I/PR, DJ de I4/08/95. A 3. Turma, contra, nos seguintes: REsp. n. 29.597-3/RS, DJ de 13/09/93; e REsp. n. 36.981-8/MG, de 23/05/94. 
relativa ao débito constante do título executivo não inibe o credor de promover-lhe a еxecução" Tal posicionamento parece-nos desnecessariamente arriscado, por comportar a possibilidade de decisões contraditórias e de ser levada a lermo execução nula.

Ademais, o referido dispositivo permite que o credor promoval" a execução, mas não impede que seja extinta, caso inobservados seus requisitos, ou suspensa, com base no poder geral de cautela de que está investido o julgador no exercício de sua função jurisdicional.

Entendemos que a inclusão deste parágrafo no texto do $\mathrm{CPC}$ tem por objetivo inibir a propositura de ações sem que haja condições para tanto, visando apenas retardar o curso da execução, pois o juiz pode levar meses até manifestar-se pela extinç̧̃̃o do processo.

\subsubsection{Exigibilidade.}

Rogério Lauria Tucci entende que o lítulo ilíquido não é, por consequiência, exigível: 'Em suma, sempre que passivel o título de crédito, ao qual a lei confere força executiva, de uma operação especificada à determinação de sua liquidez, sem que esta seja realizada ele não pode ser considerado líquido, e por via de conseqüência, resta, 'si et in quantunn'. 'inexigivel'"'?20

Data venia, discordamos do nobre jurisconsulto, por entender que exigibilidade não se confunde com exeqüibilidade, e que este conceito açambarca aquele.

A exigibilidade da obrigação se verifica pela implementação do termo ou condição inscrilos no título. Se depender de condição, para que possa transcorrer a execução, esta dependerá de prova, por ser evento futuro c incerto (art. 572 do CPC, aplicável subsidiariamente aos títulos extrajudiciais). Nos contratos bilaterais a exigibilidade passa a existir quando uma das partes cumpre com sua prestação.

Possuindo título que represente obrigação líquida e certa, c presente a exigibilidade, o exeqüente adquire o interesse de agir por meio da execução, ou seja, o título passa a ser exeqüivel.

2.3. O caso da execução hipotecária da Lei n. 5.741/71.

Com o advento do Sistema Financeiro da Habitação, instituído pela Lei n. 4.380/64, o Congresso Nacional houve por bem instituir um procedimento especílico para a execução judicial de crédito hipotecário vinculado ao SFH. Assim féz, queremos crer, procurando assegurar a viabilidade do Sistema.

19. promover. [...] 1. Dar impulso a; [...] fomentar [...] 3. /... originar [... 4. Requerer; solicitu; propondo: 'O promotor promoveu (sic) a instatraşão de processos'. 5. Diligenciar para que se realize... (HOLANDA, Aurélio Buarque de. Novo dicionário Aurélio da língua porruguesa. Rio de Janeiro: Nova Fronteira, 1986, 2a ed., p. 1401).

20. TUCCl, Rogério Lauria, "Execução - Célula de Crédito Industrial", Revista dos Tribunais, São Paulo: RT, 1989, ano 78, v. 642 , p. 3 I 
Com o tempo, o Sistema Financeiro da Habitação foi mudando de feição. Principalmente, a criação da TR, a utilização de complexos sistemas de amortização e o reajuste das prestações segundo parâmetros diversos da variação salarial dos mutuários, somados a toda a transformação no contexto sócio-econômico que vivemos desde a criação do $\mathrm{SFH}$, têm-se revelado fatores aparentes de desequilíbrio nos financiamentos imobiliários, ${ }^{21}$ ocasionando um sem-número de inadimplentes e justificando a propositura de muitas ações visando à revisão dos contratos de mútuo próprios do $\mathrm{SFH}$, c mesmo a execução lorçada de tais contratos, conforme os critérios adotados pelos agentes financeiros.

O Sistema Financeiro da Habitação foi criado para ser o meio de efetivação do direito à moradia no Brasil, antes mesmo de erigido a princípio constitucional. Sua função primordial é propiciar o direito à moradia ao povo brasileiro, e não ser mais uma fonte de renda para as bilionárias instituições financeiras, podendo, entretanto, servir, subsidiariamente, de remuneração a tais agentes financeiros, que administram seus recursos, desde que não se comprometa, com isso, a viabilidade do sistema.

A execução judicial de crédito com garantia hipotecária é regida pela Lei n. 5.741/71. Se considerado inteiramente aplicável tal diploma legal, dada sua especialidade, trata-se do modo potencialmente mais gravoso ao devedor, por ser demasiado estreita a defesa prevista nesta lei, somente admitindo o eleito suspensivo dos embargos de devedor em caso de resgate da dívida ou depósito de seu valor integral, não prevendo tal efeito nem mesmo diante da possibilidade de vício insanável do processo executivo como, por exemplo, sua fundamentação em título falso ou nulo por qualquer outra razão (art. $5^{\circ}$ da Lei n. 5.74l/7 1, caput, incisos e $\$$ único, conforme a redação dada pela Lei n. 6.014/73).

Registramos uma ocasião em que tal dispositivo foi aplicado em sua inteireza em nossos tribunais, fazendo calar os art. $5^{\circ}$. LIV e LV (que asseguram o direito ao devido processo legal, ao contraditório e à ampla defesa) e o art. $6^{\circ}$ da Constituição Federal, consoante redação dada pela Emenda Constitucional n. 26, que preceitua a moradia como direito social:

"PROCESSO CIVIL - EXECUÇÃO HIPOTECÁRIA LEIN. 5.74I/7I EMBARGOS:EFEITO (ART. 739, \& I० DO CPC).

I. Na execução hipotecária, regida por lei especial (Lei n.5.74II7I), os embargos do devedor não suspendem a execução, como regra, admitindose a suspensividade nas duas hipóteses que menciona (art. $5^{\circ}$ da lei, com a redação dada pela Lei $n$. 6.014, de 27/12/73).

21. Assim se manifestaram Walter Antonio Dias Duarte e Luis Soares de Mello Neto: "Novoss financiamentos tormam-se impraticaveis, em vista das prestaģöes iniciais e seguintes serem sobremaneira elevadus, sem qualquer possibilidade de assunçäo. Reajustes insuportáveis, a niveis incontroláveis, já que o trabalhado); na sua grande maioria, não tem seus ganhos majorados na mesma proporgāo do aumentı) das prestuşcöes". ("Considerações sobre a execução hipotecária - Penhora de outros bens além do hipotecado - Impossibilidade", Revista de Direito Civil - Imobiliairio, Agrário e Empresarial. São Paulo: RT, 1990, ano 14, n. 53 - jul./set. 1990, p. 90). 
2. O CPC, com a alteração do art. 739, \$ $1^{\circ}$ pela Lei $n .8 .953$, de 13/12/ 94, deu efeito suispensivo a todos os embargos, mas não teve a alteração o alcance de também modificar a lei especial.

3. Regra da Lei de Introdução ao Código Civil preconiza a prevalência da lei especial sobre a geral, quando divergentes (LICC art. $2^{\circ} ; 2^{\circ}$ ).

4. Recurso especial não conhecido."22

Tal entendimento afigura-se-nos equivocado, pela manifesta incompatibilidade do art. $5^{\circ}$ da Lei n. $5.741 / 71$ em face do art. $739, \$ 1^{\circ}$, do CPC, que foi redigido posteriormente àquele dispositivo, e determina que "os embargos serão sempre recebidos com efeito suspensivo (grifamos). Indubilavelmente deve ser aplicado o $\$ 1^{\circ}$ do art. $2^{\circ}$ da LICC à espécie, segundo o qual a lei posterior derroga a anterior por determinação expressa, por incompatibilidade ou por regular inteiramente a matéria, reservando-se o $\$ 2^{\circ}$ apenas para as situações em que seja possível conciliar a lei anterior com a lei nova.

Assim mesmo, para justificar o enfoque do presente artigo, bastaria simples ensejo doutrinário, absolutamente teórico, de afronta ao contraditório, à ampla defesa, ao devido processo legal e ao direito à moradia. A existência de decisão, como a retrocitada, apenas reforça a necessidade de se harmonizar a Lei n. 5.741/71 à "Constituição Cidadã" e ao Código de Processo Civil.

É bastante comum, em nossos dias, a propositura de ações visando à revisão dos contratos de fínanciamento imobiliário, acusados de conter cláusulas em contrariedade a expressas determinações legais. Tomemos como exemplo o caso do

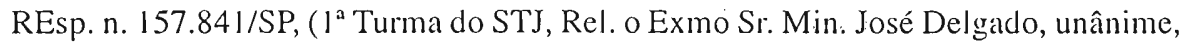
DJU de 17/04/98, p. 107):

$$
\text { '[...] }
$$

3. Nos contratos regidos pelo Sistema Financeiro da Habitação há de se reconhecer a sua vinculação, de modo especial, além dos gerais, aos seguintes princípios específicos:

a) - o da transparência, segundo o qual a infornação clara e correta e a lealdade sobre as cláusulas contratuais ajustadas, deve imperar na formação do negócio jurídico;

b)- o de que as regras impostas pelo SFH para a formação dos contratos, além de serem obrigatórias, deven ser interpretadas com o objetivo expresso de atendimento às necessidades do mutuário, garantindo-lhe o seu direito de habitação, sem afetar a sua segurança jurídica, saúde e dignidade;

c)- o de que há de ser considerada a vulnerabilidade do mutuário, não só decorrente da sua fragilidade financeira, mas, também, pela ânsia e 
necessidade de adquirir a casa própria e se submeter ao império da parte financiadora, econômica e financeiramente muitas vezes mais forte; d)- o de que os princípios da boa-fé e da equiidade devem prevalecer na formação do contrato.

4. Há de ser considerada sem eficácia e efetividade cláusula contratual que implica em reajustar o saldo devedor e as prestações mensais assumidas pelo mutuário, pelos índices aplicados às cadernetas de poupança, adotando-se, conseqüentemente, a imperatividade $e$ obrigatoriedade do Plano de Equivalência Salarial, vinculando-se aos vencimentos da categoria profissional do mutuário.

5. Recurso improvido."

Trata-se de decisão extremamente favorável aos mutuários, considerandose que a maioria dos contratos tem adotado a Taxa Referencial (TR) para reajustar o saldo devedor e as prestações de tais financiamentos.

Ocorre que, por vezes, os credores hipotecários não observam a conexão entre a ação revisional e a execução, tampouco a prevenção do juízo da ação revisional, propondo a execução em outro Foro. Também a incerteza que havia quanto à competência para julgar tais causas deu azo a esse tipo de desencontro, por haver dúvida se a União Federal e a Caixá Econômica deveriam, na qualidade de sucessoras do $\mathrm{BNH}$, Integrar o pólo passivo de todas as lides, mesmo nos financiamentos realizados por outros agentes financeiros. Vejamos:

\section{"MANDADO DE SEGURANÇA. FINALIDADE CAUTELAR. ATO JUDICIAL TERATOLÓGICO.}

$O$ ato judicial que resulta de sentença que violou coisa julgada se sujeita, excepcionalmente, a controle cautelar na via do mandado de segurança, quando a ação rescisória a ser ulteriormente ajuizada é insuficiente à tutela jurisdicional efetiva. Hipótese em que, tendo obtido na Justiça Federal o reconhecimento de que o reajuste de prestações de mútuo hipotecário vinculado ao Sistema Financeiro da Habitação era abusivo, segue-se o aparelhamento de execução na Justiça Estadual à base dos valores pretendidos pelo Agente Financeiro, depois de mal sucedidos embargos do devedor relatando a existência da sentença proferida na outra jurisdição. Mandado de segurança concedido, en parte. "2.3

Nesses casos, a interpretação literal do art. 585, $\$ 1^{\circ}$, do CPC, simultaneamente ao entendimento expresso pela $2^{\mathrm{a}}$ Turma do STJ no REsp. 196.297$\mathrm{SC}$ (v. supra, item 2) poderia afrontar princípios basilares do processo civil, ameaçando

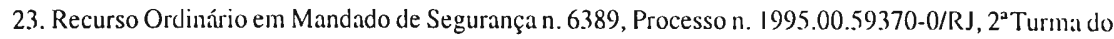
STJ, Rel. o Exıno. Sr. Min. Ari Pargendler, publicado no DJU de 22/04/1996, p. 12555 e na RSTJ, v. 83, p. 92. 
mesmo a segurança jurídica, pela ocorrência de respostas dissonantes. Isso se antes não ocorresse a extinção da ação revisional, pela perda de seu objeto - o que atacaria os princípios constitucionais do acesso à Justiça, do devido processo legal, do contraditório e da ampla defesa (art. $5^{\circ}, \mathrm{XXXV}$, LIV e LV da Constituição Federal).

E se posteriormente viesse a ser declarado o direito dos muluários, terse-ia configurada uma situação teratológica, por ter sido levada a termo execução nula com base em título representativo de obrigação ilíquida - c, por vezes, alé mesmo incerta $^{24}$ O próprio Alcides de Mendonça Lima, a única voz da doutrina nacional que se levantou absolutamente contra a delesa do devedor sem a segurança do juízo, em parecer solicitado pela COPERSUCAR (que então movia execução contra a Central Paulista de Açúcar e Álcool) ${ }^{25}$ adverte:

"A execução nula é um mal para o devedor, porque o perturba inutilmente, embora sem vantagem fïnal para o credor, no momento en que a mulidade for declarada. Se viciadamente movida, pode prejudicar o devedor, moral e economicamente, em seus negócios, inclusive sujeitando-o ao ônus de ter de embargar, se o Juiz, 'ex officio' não houver trancado o processo, indeferindo o pedido." 20

Imagine-se então o que diria o eminente jurisconsulto sobre a execução nula levada às últimas conseqüências, em evidente ofensa ao princípio da litularidade.

Assim, enquanto não for líquida a dívida exigida pelo credor, restando ainda a cognição de elementos não constantes do título executivo, mesmo a exigência de penhora representaria injustificado óbice à defesa do devedor: "Se o título não for exequiivel, não tem sentido a penhora, desaparece seu fundamento lógico e jurídico. [...] Seria iniqüidade absurda, que o Direito e o bon senso não podem acolher; se, em tal hipótese, se impusesse à defesa o grave ônus da penhora" 27

24. “...quanto ao tímlo extrajudicial, ele ou é líquido, e, portanto, tínulo; ou não é líquido, e, por isso. refoge ao gabarito de título executivo." (ASSIS, Araken de, op. cit., p. 131).

25. LIMA, Alcides de Mendonça. Processo de conhecimento e processo de execuşäo (nova série) Rio de Janeiro: Forense, 1993, pp. 275-290.

26. LIMA, Alcides de Mendonça. Comentários an Códligo de Processo Civil. Rio de Janeiro: Forense, 1974, T. II, v. VI, p. 66I, n. 1485, apud BOJUNGA, op. cil., p. 69 - grilamos

27. LACERDA, Galeno, "Execução de título extrajudicial e segurança do juízo", Revisı Ajıris, n. 23, Porto Alegre: Associação dos Juízes do Rio Grande do Sul, 1981, 12. 23, p. 7. Neste mesmo sentido: NETTO, (p). cit., pp. 32-33; MOREIRA, Alberto Camiña. Defesa sem embargos do executado. São Paulo: Saraiva, 2000, passim. SILVA, José Vilaço da, op). cit., p. 14; BOJUNGA, Luiz Edinundo Appel, op). cit., 67-70; MILHOMENS, Jônatas, op. cit., p. 204; GRECO, Leonardo, op. cit., 624-627; GONÇALVES NETO, Francisco. "Exceção ou objeção de pré-executividade" Revistu LTi: São Paulo: LTr; 2000, ano 64, n. 5, maio, p. 616; MOREJRA, Lenice Silveira, op. cit., pp. 102-89, passim; PEREIRA, Tarlei Lemos. “Exceção de pré-executividade". Revista dos Tribunais. São Paulo: RT, 1999, ano 88, v. 760), fevereiro, p). 773; MOLITOR, Deborah de Araújo. "Reflexões sobre a exceção de pré-executividade", Revista da Faculdade de Direito de São Bernardo do Campri. São Bernardo do Campo: Faculdade de Direito de São 
3. A Exceção de Pré-executividade.

Exceção de pré-executividade - exercício do poder geral de cautela em sede de exceção cle pré-executividade - limites ao poder geral de cautela.

Vindo para banir definitivamente de nosso sistema jurídico lormal ismos supérfluos que ameaçam a efetividade da prestação jurisdicional, o art. 154 do Código de Processo Civil, genericamente, preceitua: "Os atos e termos processuais não dependem de forma determinada senão quando a lei expressamente a exigir; reputandose válidos os que, realizados de outro modo, the preencham a finalidade essencial"

À Juz deste princípio do Direito Processual Civil, consideramos incontestável a validade da exceção de pré-executividade enquanto instrumento processual. Contudo, seu espectro de aplicação limila-se às matérias de ordem pública, que podem ser conhecidas de ofício pelo julgador, inclusive condições da ação c pressupostos processuais (tanto os genéricos, quanto os especílicos do processo de execução, relativos à validade do lítulo executivo), e também as matérias usualmente argüíveis por meio de exceção (como a incompetência relativa), além da decadência e da prescrição. ${ }^{2 x}$ Também a Jurisprudência vem aceitando largamente o instituto, o que ilustramos com a seguinte decisão:

\begin{abstract}
"PROCESSUAL CIVIL. EXECUÇÃO. EXCEÇÃO DE PRÉEXECUTIVIDADE. ADMISSIBILIDADE. CONTRATO DE ABERTURA DE CRÉDITO. TÍTULO EXECUTIVO. INEXISTÊNCIA. ART. 585, II, CPC. I. É possivel ao devedor acionado no processo de execução argiiir a nulidade da execução, por meio de exceção de pré-executividade e não de embargos, desde que verse sobre matéria que possa ser conhecida de ofício pelo Juizo.
\end{abstract}

Bernardo do Campo, 2000, vol. 6, tomo I, p. 57; CAIS, Cleide Previtalli. "Exceçĩo de pré-executividade em execução fundada em título executivo extrajudicial", Revista Dialética de Direito Tributúrio. São Paulo: Oliveira Rocha, 1999, n. 43, abril, pp. 26-29; MAGALHĀES, Jorge de Miranda. "A Execuçũo e a exceção pré-processual", Revisıa de direito do Tribunal de Justiça do Esıado do Rio de Janeiro. Rio de Janeiro: TJRJ, 1995, n. 25, out./dez., pp. 15-21 passim; DAL COL, Helder Martinez, op. cit., pp). 198-197; ANDRADE, José Batista de. "Exceção de pré-executividade", Revista Síntese de Direito Civil e Processutal Civil. Porto Alegre: Síntese, 2001, ano II, n. 10, mar/abr., pp. 60-62; SÁ, Rodrigo Cesar Caldas de. "Exceção de pré-executividade e Fazenda Pública: pode alguém ser submetido a processo executivo sem pressupostos ou condições constituição ou desenvolvimento regular?", Revista Dialética de Direito Tributírio. São Paulo: Oliveira Rocha, 2000, n. 53, fevereiro, pp. 95-104 passim; CORREIA, Marcos Orione Gonçalves. "Aspectos da exceção de pré-executividade no processo civil e sua admissibilidade no processo do trabalho", Revisıa de direito do lrabalho. São Paulo: RT, 2(001, ano 27, n. I ()2, abr./jun., p). 83; FORNICIARI JR., Clito. "Exceção de pré-executividade", Revista Símese de Direilo Ciril e Processual Civil. Porto Alegre: Síntese, 2000, ano I, n. 4, mar./abr., p. 30; FANTONI JR:, Neyton. "Exceção de préexeculividade: limites e possibilidades", Revista Símese de Direito Civil e Processual Civil. Ponto Alegre: Síntese, 2000, ano II, n. 8, nov./dez., p. 18-19. Contra: LIMA, Alcides de Mendonça. Processor de comhecimento e processo de execusano (nova série). Rio de Janeiro: Forense, 1993, 279-290 passimt.

28. V. nota 27, supra. 


\section{Precedentes da $4^{a}$ Turma.}

III. O contrato de abertura de crédito em conta corrente, ainda que acompanhado de extratos de movimentação financeira, não constitui título hábil à promoção de ação executiva.

IV. Recurso conhecido e provido." ${ }^{29}$

3.1. O exercício do poder cautelar geral do juiz no âmbito da exceção de préexecutividade.

Greco Filho fundamenta o poder cautelar do juiz nos arts. 798 e 799 e justifica a sua existência "porque não poderia prever o legislador todas as hipóteses em que bens juridicos envolvidos no processo fiquem em perigo de dano e muito menos todas as medidas possiveis para evitar que esse dano ocorra"30

O provimento cautelar surge no ordenamento jurídico brasileiro, como em diversos outros, da necessidade de se garantir a efetividade da prestação jurisdicional estatal, ameaçada pelo perigo de dano ao direito pleiteado na ação existente ou a ser ajuizada pelo titular deste direito.

Este provimento cautelar pode se dar em sede de ação cautelar, que instaura o processo cautelar, tratado no Livro III do CPC ou pode se dar em sede de medida cautelar atípica ${ }^{31}$ (ou inominada) incidental no processo, seja de conhecimento ou seja no de execução ${ }^{32}$, fundamentado no poder geral cautelar do juiz, que se expressa principalmente no art. 798 do CPC. A medida cautelar concedida assim, incidentalmente, sem processo autônomo, o será, portanto, em sede de decisão interlocutória ${ }^{33}$

Neste mesmo diapasão, Greco Filho diz:

"O poder cautelar geral do juiz atua sob duas formas: a) quando a parte, presentes ou pressupostos, requer a instauração, preventiva ou incidental de processo cautelar, pleiteando a medida não prevista no rol legal e, portanto, chamada inominada; b) nos próprios autos do processo de conhecimento ou de execução, quando una situação de emergência exige a atuação imediata do juiz independentemente de processo cautelar e mesmo de iniciativa da parte".34

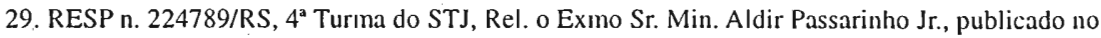
DJU de 04/02/2002, p. 370.

30. GRECO FILHO, Vicente. Direito Processual Civil Brasileiro. São Paulo: Saraiva, 1994, $8^{2}$ ed., v. 3, p. 154.

31. Cf. ALMEIDA, Jorge Luiz de. Liminar Cautelar em Procedimento Comum. 1992. Tese (Doutorado em Direito) - Faculdade de Direito, Universidade de São Paulo, São Paulo. Orientador: Prof. Cândido Rangel Dinamarco, p. 63.

32. Idem, ibidem, p. 125-126.

33. Idem, ibidem, p. 49.

34. GRECO FILHO, Vicente, op. cit., p.156. 
Discutindo a possibilidade de serem concedidos provimentos cautelares em processo de conhecimento ou execução, Greco Filho entende que se a lei previr esta hipótese, as medidas serão deferidas, ou não, independentemente da instauração de um processo cautelar ${ }^{3.5}$

Entende este mestre que, se a lei não previr medida cautelar no próprio procedimento do processo de conhecimento ou execução, então, em princípio, o juiz não pode decidir sobre pedido dessa natureza, cabendo à parte pleitear este pedido em processo cautelar instaurado formalmente ${ }^{36}$

Porém, tratando-se de bem ou pessoa sob a responsabilidade do juiz, ou se:

“...o estado da causa, sem necessidade de qualquer outro elemento de instrução, permite o exame e decisão sobre pedido de medida cautelar, não há óbice a que a proteção seja deferida, especialmente se a demora do próprio processo cautelar puder causar dano à parte e esta circunstância ficar demonstrada nos autos" ${ }^{37}$.

A questão incidente no processo, como a que pode ensejar um provimento cautelar do juiz, é definida por Dinamarco como:

“...aquela que aparece no processo pendente, ou seja, incide sobre ele (in-cidit $=$ cai). O direito positivo determina que certas questões dessa ordem sejam discutidas e obtenham solução mediante instauração de incidentes de processo [...]. Não confundir incidente de processo com processo incidente. Aquele é um acontecimiento do processo mesmo, un pequeno procedimento paralelo ao principal, determinando ou não a suspensão deste mas sempre se integrando no processo já antes pendente, sem dar origem a um outro; processo incidente é processo novo, outro processo que tem vida em função do primeiro, que produzirá sentença destinada a projetar efeitos sobre ele [...]. A mais relevante consequência desta distinção é que os incidentes de processo têm fin miediante decisão interlocutória, sujeita a agravo, enquanto que a sentença é ato que põe fim ao processo incidente" (grifamos) ${ }^{3 \mathrm{~K}}$

Sanches define o poder cautelar do juiz, dizendo que ele "consiste na jurisdição que exerce, acautelando provável direito da parte, com medidas não previstas

35. Idem, ibidem, p. 166

36. Idem, ibidem.

37. Idem, ibidem.

38. DINAMARCO, Cândido Rangel. Fundamentos do Processo Civil Moderno. São Paulo: RT, 1987, $2^{\mathrm{a}}$ ed., pp. 172-173. 
especificamente pelo Código, acrescentando, a seguir, que ele tem fonte nos arts. 798 e 799 do CPC. Mas o exercício desse poder faz-se com obediência às normas gerais do processo e procedimento cautelar, que estão entre os arts. 796 e 812 do CPC" 3. Acrescenta ainda: "Qucais são as hipóteses, então, em que o juiz exercita o seu poder cautelar geral? As hipóteses são infinitas. A vida prätica pode oferecer situações tão variadas e variáveis, que na mesma medida, variarão as providências cautelares deferidas ao Juiz". "1"

Em relação ao âmbito processual em que o juiz pode exercitar seu poder geral cautelar ele diz que o poder cautelar geral do Juiz exercita-se através de provimentos em ações cautelares ou simples medidas cautelares. ${ }^{41}$

Logo, depreende-se, em uma cognição preliminar, que para Sanches o poder cautelar geral do juiz pode ser exercido em sede de processo e procedimento cautelar, mas também, no que também ele denominou de "medidas cautelares" Ora, por decorrência lógica, estas medidas, deferidlas fora do âmbito da ação cautelar, e portanto, do processo cautelar, só seriam possíveis em decisões interlocutórias prolatadas em processos de conhecimento e de execução.

Para melhor compreensão da matéria, é melhor diferenciar a medida cautelar da ação cautelar, pois toda ação cautelar é uma medida cautelar, mas nem toda medida cautelar é uma ação cautelar, já que a primeira pode ser concedida em decisão interlocutória em um outro gênero de processo. Para evitar a confusão entre estas medidas cautelares concedidas em decisões interlocutórias, e as medidas cautelares concedidas em sede de ações cautelares, passaremos a denominar as primeiras provimentos cautelares.

Acrescenta, ainda, Sanches, que "o juiz não pode de ofício determinar medidas cautelares genéricas ou específicas, senão quando expressamente autorizado por lei. O próprio Código contém algumas normas permissivas de provimentos cautelares pelo juiz, de oficio". A seguir exemplifica com os art. $793 \mathrm{c} 653$, ambos do CPC ${ }^{42}$

Estes dispositivos estão no Livro II do CPC, sendo, portanto, medidas cautelares determinadas pelo juiz no excrcício do seu poder geral de cautela fora do processo cautelar, como provimento cautelar incidental ao processo de execução, o que só reforça o entendimento exposto acima, da possibilidade do provimento cautelar amplo, nas infinitas hipóteses, em qualquer gênero de processo. Inclusive no de execução.

Devemos observar que os arts. 798 e 799 estão no Livro III do CPC, que trata do processo cautelar. Assim, estes dispositivos fundamentam o exercício do poder cautelar geral do juiz no processo e procedimento cautelar. O exercício deste poder no

39. SANCHES, Sydney. "Poder Cautelar Geral do Juiz", Revista Ajuris. Porto Alegre: Associaçĩo dos Juízes do Rio Grande do Sul, 1988, ano XV, n. 44, nov., p. 59.

40. Idem, ibidem, p.63.

41. Idem, ibidem, p. 65.

42. Ibidem, p. 60 . 
âmbito de decisões interlocutórias, em sede dos demais gêneros de processo, não sc encontra explicitamente insculpido no CPC, mas depreende-se dos arts. 793, 653 e diversos outros, salientando-se que eles elencam exemplos destes exercício de poder cautelar geral, e que não esgotam as possibilidades onde poderá o juiz da causa exercê-lo.

Pelo contrário, uma interpretação sistêmica com o art. 798 só cvidencia que este poder cautelar geral do juiz no âmbilo de outros processos, que não o cautelar e, portanto, em sede de decisões interlocutórias, é extremamente amplo quando o perigo de dano ao direito da parte surge como questão incidental.

Galeno Lacerda aponta, inclusive, que a liminar nos procedimentos que a prevê "nada mais é do que um ato que torna manifesta a função cautelar do magistrado, quando presentes o risco de lesão e a verossimilhança do direito ameaçado e que neste sentido, todas as liminares possuem, sem divida, natureza cautelar" $\$, 3$ (grifamos). No mesmo sentido Lima, Barbi e Sidou entendem tratar-se, a liminar, de "providência cautelar" 44

Assim, pode-se por decorrência lógica, inferil que a concessão de liminares nos processos de conhecimento e de execução, ć lambém uma expressão do poder cautelar geral do juiz fora do âmbito do processo cautelar.

Admitindo-se, assim, o exercício do poder geral de cautcla do juiz, atlavés de decisão interloculória, resta saber se cxiste forma legal para cla. Ora, como estas medidas provisória cautelares são atípicas, não têm lorma legal prevista, sendo limitadas pelos princípios cmanados da ordem constitucional e do sistema processual ${ }^{+5}$

Esta concepção se fundamenta lambém no princípio da liberdade da forma, do qual trata Portanova que sobre ele alirma:

“...o processo civil libertou-se completamente do formalismo em relação aos atos processuais. ${ }^{46}$ Adotando o princípio da liberdade das formas, o processo civil brasileiro afaston a incidência do princípio da legalidade da forma. Dessa maneira a exigência de determinada forma para deterninados atos está restrita às hipóteses taxativa e expressamente previstas em lei" 47

43. LACERDA, Galeno. "Limites ao Poder Cautelar Geral e a Concessão de Liminares". Revisıa Ajuris. Porto Alegre: Associaçĩo dos Juízes do Rio Grande do Sul, 1993, ano XX, n. 58, jul., 95-104, citei p. J0।

44. Apual MANCUSO, Rodol fo de Camargo. "A Questāo dos limites no Poder Cautelar Geral”, Revista do Tribunal de Comias do Município de São Paulo. São Paulo: 2000, ano II, n. 7, PI a P96, Se1., p. 66.

45. Cf. ALMEIDA, Jorge Luiz de, op. cir., p. 110.

46. PORTANOva, Rui. Princípios do Processo Civil. Porto Alegre: Liviaria do Advogado, 1995 , p. 186. Além disso, o art. 154 do CPC diz que: "Os atos e termos não dependem de forma determinada senão quando a lei expressamente exigir; reputando-se válidos os que realizados de outro modo. lhe preencham "finalidade exsencial" Ora, pela exegese deste dispositivo conclui-se que, se a lei não exige expressimente forma determinada para concessão de provimento cautelar fora do âmbito do processo cautelar, este provimento poderá ser solicitado sem rigor formal.

47. PORTANOVA, Rui, op. cit., p.187. 
Por decorrência lógica, se estas medidas provisórias cautelares, que chamaremos provimentos cautelares, não têm forma estabelecida em lei, como já vímos acima, e podem ser incidentalmente pronunciadas no âmbito de qualquer processo, e, portanto, também no processo de execução, ${ }^{4 x}$ então elas podem ser requeridas em sede de exceção de pré-executividade, para suspender a execução quando desta decorre lesão a direito do executado.

Basta, para tanto, que estejam presentes os requisitos para sua concessão: o funus boni iuris e o periculum in mora. O fumus boni iurus pode ser relativo ao direito de ação ou ao direito material invocado no processo que decorre deste direito ação.

Em posição contrária, entendendo que o poder cautelar geral do juiz só pode ser exercido no processo cautelar, outros doutrinadores, dos quais destacamos Humberto Theodoro Júnior. ${ }^{49}$

Flavio Cheim Jorge, sustenta a mesma posição, dizendo que "a concessão da liminar com base no poder geral de cautela, somente pode ser concedida no bojo de um processo cautelar. Não é possível, assim, a utilização do Poder Geral de Cautela, em processo de conhecimento ou execução" "50

Ora, data maxima venia, podemos dizer, em concordância com Galeno Lacerda e Greco Filho, entre outros, conforme exposto acima, que todas as liminares têm caráter de provimento cautelar. Acontece que nem todo provimento cautelar se dá em sede de liminar. Assim, se considerarmos, como afirma Cheim, que o exercício do poder cautelar geral do juiz em sede de liminar só pode se dar no processo cautelar, então, por decorrência lógica, as demais liminares existentes no CPC, segundo o entendimento dele, não teriam natureza cautelar ou, então, que as outras liminares previstas expressamente no CPC não seriam expressões do poder cautelar geral do juiz.

Ora, se analisarmos as liminares previstas no CPC, observaremos que todas têm por escopo evitar lesão à parte, quando ameaçada a efelividade da prestação jurisdicional por ela pleiteada. Por exemplo, na ação de nunciação de obra nova, prevista no Livro IV do CPC, Dos Procedimentos Especiais, a qual não é um processo cautelar, pois estes estão previstos no Livro III deste diploma legal, a liminar prevista no art. 937 do CPC visa evitar o dano, se iminente, que a edificação de obra nova em imóvel vizinho possa acarretar ao prédio, servidões ou fins ao qual é destinado pelo seu proprietário (art. 934 do CPC).

A liminar é concedida caso exista a possibilidade deste dano ocorrer antes da decisão transitada em julgado na ação de nunciação de obra nova. Isto não é um provimento cautelar? Do mesmo modo, são provimentos cautelares a liminar que

48. ALMEIDA, Jorge Luis, op. cit., p. 125-126.

49. Apud PINTO, Nelson Luiz. "Medidas Cautelares - Poder Cautelar de Juiz", Revisfa de Processio. São Paulo: Ed. RT, 1990, ano 15, jul./set., n. 59, p. 185.

50. JORGE, Flávio Cheim. “O Processo Cautelar e o Poder Geral de Cautela do Juiz". Revista de Processo. Ed. RT, 1997, ano 22, jul./set., n. 87, p.194. 
pode ser concedida no interdito possessório (arts. 932, 933, 928-931 do CPC), pois ela será concedida para garantir o direito do possuidor direto ou indireto de gozar a sua posse sem ser molestado por outrem diante da iminência de que este esbulho ocorra. A liminar concedida no âmbito desta ação está garantindo a efetividade da tutela jurisdicional a ser nela prestada, sendo, portanto, igualmente um provimento cautelar. No sentido de que liminares são expressão do poder cautelar geral do juiz, conforme o nosso entendimento, colamos aqui decisão do STJ, a título ilustrativo, no mesmo senticlo:

\section{"PROCESSO CIVIL. CONFLITO DE ATRIBUIÇÕES. PODER CAUTELAR GERAL. \\ De conformidade com o poder cautelar genérico inerente à função jurisdicional, é lícito ao relator do conflito de atribuição ordenar as medidas urgentes que entender necessárias à proteção de qualquer direito suscetivel de grave dano de incerta reparação ou ainda destinadas a garantir a eficácia de ulterior decisão da causa. Inteligência dos arts. 124 do CPC; 24 , parágrafo único do ato regimental n. 0I/89, do STJ, I66 do RISTF; 33, ns. V e vi, do RITRF. Precedente do STF. Agravo regimental a que se nega provimento."}

Monteiro:

Destacamos desta decisão as palavras do Ministro Relator Barros

"Como se sabe, o deferimento da medida liminar, que resulta do concreto exercício do poder cautelar geral outorgado aos juizes e Tribunais, somente se justifica em face de situações que se ajustem aos pressupostos referidos no art. $7^{\circ}$, II, da Lei $n$. 1.533/51: a existência de plausibilidade juridica (fumus boni juris), de um lado, e a possibilidade de lesão irreparável ou de difícil reparação (periculum in mora), de outro" (grifamos). ${ }^{51}$

Assim, se o CPC prevê provimentos cautelares, como acima provado, em sède de liminar ou não, em outros processos que não os cautelares, a fonte deste poder cautelar só pode ser o poder cautelar geral do juiz, o qual pode, portanto, ser exercido no âmbito de processos de conhecimento e de execução, ao contrário do sustentado por doutrinadores como Theodoro Junior e Cheim.

Isto posto, passaremos a examinar o provimento cautelar incidental ao processo em sede de decisão interlocutória e particularmente no processo de execução hipotecária previsto na Lei 5.741/71.

51. AGRCA - Agravo regimental no conflito de atribuição n. 3. Processo n. 1989.00.08773-8/DF. $2^{\text {a }}$ Seção do STJ, relator o Exmo. Sr. Ministro Barros Monteiro, por maioria. Publicado no DJU de 02/10/ 1989, p. 15344. 
De fato, o art. 798 do CPC dispõe que: Além dos procedimentos cautelares específicos, que este Código regula no cap. II deste Livro poderá o Juiz determinar as medidas provisórias que julgar adequadas, quando houver fundado receio de que uma parte, antes do julgamento da lide, cause ao direito da outra lesão grave de difícil reparação (grifamos).

A exegese deste dispositivo nos indica, inequivocamente, que o legislador pretendeu colocar nas mãos do juiz um quase infinito rol de medidas cautelares provisórias, além daquelas nomeadas no $\mathrm{CPC}$, desde que presentes os requisitos para a sua concessão, sempre que seja necessário evitar lesão de difícil reparação a direito de uma das partes, não restringindo, contudo - como se conclui da simples leitura deste dispositivo - que csla medida seja exclusivamente em sede de processo cautelar autônomo, podendo, por decorrência lógica, ser cm sede de decisão interlocutória nos demais gêneros de processo, inclusive nos processos de jurisdição voluntária ${ }^{52}$

Ainda que se argumentasse que este dispositivo legal está inserido no Livro III do CPC, que trata dos processos cautelares, e que, portanto, só se aplicaria aos processos cautelares, deve-se considerar que, comos expomos anteriormente, o próprio CPC prevê expressamente medidas cautelares incidentais em outros gêneros de processos como, por exemplo, o art. 793 do CPC, que trata da suspensão da execução e faculta ao juiz ordenar os provimentos cautelares urgentes (grifamos) e o já citado aqui, art. 615 do CPC. Logo, em uma análise sistemática do CPC, observa-se que o legislador pátrio conferiu ao poder cautelar geral do juiz, transcendência ao processo cautelar em si, podendo ser exercido nos demais gêneros processuais, como o processo de conhecimento ou de execução.

Além disso, em nenhum momento os arts. 798 e 793 do CPC mencionam que este provimento cautelar tenha que ser, obrigatoriamente, provocado pelo parte, podendo, portanto, ser determinado ex officio, presentes seus requisitos concessivos, ou seja: o fumus boni iuris e o periculum in mora, no exercício da discricionaridade do juiz, expresso no art. 798 do CPC pela expressão que julgar adequada, já que discricionaridade é o julgamento de oportunidade e conveniência.

Esta expressão também indica que o juiz, ao dar o provimento cautelar, pode escolher o tipo de provimento, o que indica a ampla liberdade de hipóteses nas quais os juiz pode dar o provimento cautelar solicitado pela parte, ou mesmo ex officio.

Galeno Lacerda nos ensina:

"...exatamente porque provém de norma amplissima, que confia a consciência, a ponderação, a prudência do juizo, critério de, segundo seu justo arbítrio, motivado pela exigência e valoração dos fatos, determinar as medidas provisórias que julgar adequadas, não há como

52. Cr. SAMPAIO, Marcus Vinicius de Abreu. O Poder Geral de Cautela do Juiz. São Paulo: RT, 1993, pp. 203 e $209-210$. 
fugir a consideração de que estamos en presença, aqui, de un vastíssimo poder geral discricionário". ${ }^{53}$

Acrescenta, ainda, este mestre: "Nenhuma incompatibilidade também ocorre entra a cautela e a execução. I... I Nada impede, porém, conforme as circunstâncias, se empreguem ainda outras medidas, inclusive atípica.t.s" $5+$

Assim, entendemos, no mesmo diapasão, que é totalmente cabivel o provimento cautelar incidental em sede de processo de execução (inclusive a execução hipotecária prevista na Lei 5.741/71), no exercício do poder geral de caulela do juiz, sem que seja necessário o ajuizamento de uma ação cautelar incidental, atendendo-sc assim ao princípio da econonia processual e ao princípio da necessidade.

Greco Filho explica da seguinte forma o princípio da economia processual: "Quando duas forem as soluções legais possiveis, deve ser adotada a que causar menos encargos às partes. Economia não quer dizer a supressão de atos previstos no modelo legal do procedimento, mas sim a escolha da alternativa menos onerosa, se mais de uma for legalmente admissivel" 55

Moacyr dos Santos se refere a este princípio do seguinte modo: "Recomenda o principio que se obtenha o máximo resultado na atuação da lei como minimo emprego possivel de atividades processuais" sh

Sandin cntende que:

"...se o executado tiver ainda a possibilidade de opor embargos ì execução, onde se ajuizados, suspenderão o curso procedimental deste processo, não haverá interesse processual cautelar para aforar medida de prevenção para obstaculização da marcha da execução. Todavia, esgotado o prazo para a oferta dos embargos, sem a sua propositura, se o devedor possuir elementos para intentar ação descontitutiva do título exequendo e, além disso, puder vir a sofrer lesão grave e de difícil reparação, com a tramitação da ação executiva, entendemos praticável a cautelar inominada para obstar; temporariamente, o 'iter" do processo de execução. Esta cautela poderá ser antecedente ou incidente à ação de desfazimento do título executivo (demanda esta que poderá ser: rescisóriatítulos executivos judiciais, ou anulatória-para os extrajudiciais". 57

53. LACERDA, Galeno. Comentairios ao Código de Processo Civil. São Paulo: Forense, 1980, v. VIII, Tomo 7, p. 138.

54. Idem, ibidem, pp. 57-58.

5.5. GRECO FILHO, Vicente, op. cit., v. 2, p. 82.

56. SANTOS, Moacyr dos. Primeiras linhas do Direino Processual Civil. Sĩo Paulo: Saraiva, 1977. $3^{\mathrm{a}}$ ed., v. Il, p. 5.5 .

57. SANDIM, Emerson O. "Medida Cautelar para Suspender Processo de Execução", Revista do Curso de Direito da Universidade Federal de Uberlândia. Uberlândia, 1992, v. 21, 11. 1/2, p. III. No mesmo sentido: SANTOS, Emani Fidélis dos. Mamual de Dirciuo Processialal Civil. São Paulo: Saraiva, 1987, v.3, p.116. 
Como a Lei n. 5.741/71, ao disciplinar a execução judicial da hipoteca, prevê, no seu art. $5^{\circ}$, que os embargos à execução não têm efeito suspensivo exceto nos dois casos que apresenta, se deduz, obviamente, que seria cabível a medida cautelar para sustar esta execução até julgamento da ação em que se discuta a existência ou não deste débito e seu quantum.

Ocorre que, como demonstramos anteriormente, este provimento cautelar pode ser requerido incidentalmente, neste e em qualquer outro processo de execução ou de conhecimento, em atendimento ao princípio da economia processual a a princípio da necessidade, para ser decidido em interlocutoriamente. Como não há exigência legal de forma determinada para este ato, a exceção de pré-executividade pode e parece ser o veículo mais adequado para o requerimentó deste provimento cautelar em decisão interlocutória.

Tudo com o fïm de salvaguardar o direito tutelado naquela execução, oú o direito material discutido, ou a ser discutido em outra ação, cuja efetividade seja por esta execução prejudicada, atingindo assim o direito da parte à devida prestação jurisdicional estatal, a que todos têm direito, por força do princípio da efetividade jurisdicional.

É esse exatamente o caso da execução judicial de hipoteca pela Lei n. $5.741 / 71$, na qual o suposto devedor tem direito à efetividade da ação revisional de prestações e saldo devedor por ele proposta, cuja sentença pode alterar o valor da dívida que ensejou a execução judicial, ou mesmo declarar a inexistência da dívida pela quitação do financiamento do imóvel.

Este provimento cautelar, em decisão interlocutória, como expressão do poder geral de cautela do juiz, atende ao princípio da economia processual, pois se este provimento cautelar não fosse concédido deste modo, a parte teria que ajuizar uma outra ação para obter a efetividade da prestação jurisdicional naquele processo, ou seja, uma ação cautelar incidental, ou preparatória, o que traria mais despesas para a parte e cumularia o Judiciário com o encargo de um novo processo, quando a questão poderia ser simplesmente resolvida com a concessão da cautela através de uma decisão interloculória.

O juiz de uma determinada ação pode inclusive, em nosso entender, prover cautelarmente medida provisória incidental para garantir a efetividade de ação que esteja sendo julgada por outro júiz, pois, neste caso, sua atuação integra a administração do processo, e o direito a ser protegido é o direito público ao bom funcionamento do Estado em sua atividade jurisdicional. Havendo conexão de causas, estas deverão ser juntadas no juízo prevento, que manterá a cautela ou não.

Assim, o juiz de uma ação de execução judicial hipotecária, prevista na Lei n. 5.471/71, pode cautelarmente suspendê-la ex officio ou a requerimento da parte lesada, para evitar que uma ação de conhecimento revisional de prestações e saldo devedor do financiamento, existente, ainda que a ré não tenha sido citada, ou a ser ajuizada pelo devedor, perca sua efetividade, devendo, contudo, serem juntados, $e x$ officio ou a pedido das partes, os processios conexios, caso estejam em juízos diferentes, considerando a prevenção como critério óbvio de escolha do juízo competente. 
3.2. Os limites do poder cautelar geral do juiz.

Sanchez aponta como limites ao poder cautelar geral do juiz, que este não pode, "no processo cautelar, em caráter provisório, conceder tutela mais ampla do que aquela que a parte poderia obter, em termos definitivos, no processo de conhecimento ou de execução. O mais há de ser sempre questão de prudência" 58

Acrescentamos a este limite, mas tangenciando o limite dos ditames da prudência, que se o provimento cautelar, seja ele concedido em sede de ação cautelar ou em outro gênero de ação, criar risco muito maior de causar dano irreparável à parte requerida que o risco de dano à parte requerente da cautela, o provimento cautelar requerido não pode ser concedido, por prudência.

Galeno Lacerda também chama a "atenção para a prudência de que se deve revestir o magistrado no uso do poder cautelar geral"..$^{99}$

Por esta razão, é extremamente importante a aplicação do princípio do contraditório, para que todas as partes possam se manifestar, e o juiz proferir sua decisão, avaliando devida e profundamente as conseqüências concretas do deferimento, ou não, do provimento cautelar à parte - ou no caso dos provimentos cautelares emergenciais inaudita altera pars, para que o juiz mantenha, ou não, este provimento, posteriormente.

Assim, quando o requerimento de provimento cautelar se der no âmbito do processo de conhecimento ou de execução, a outra parte, havendo tempo hábil para isso antes que o dano se concretize, deve ser ouvida antes de sua concessão, e se o juiz conceder de ofício este provimento, a prudência aconselha que as partes sejam ouvidas com antecedência, exceto na hipótese de que o conhecimento da parte do provimento cautelar iminente possa torná-lo ineficaz.

O fundamento jurídico para esta hipótese se encontra no art. 804 do $\mathrm{CPC}{ }^{\text {(x) }}$ que em uma interpretação sistemática e por analogia pode também ser aplicado nos provimentos cautelares em sede de processos de conhecimento ou execução

Mancuso, com receio de abuso de concessão de medidas cautelares, discrimina uma série de limitações, entre as quais destacamos "que a cautela não tenha abrangência maior do que o provimento que poderia ser obtido 'principaliter'; [...] c) que a liminar seja concedida quando se afigurar viável, ainda que a nivel de plausabilidade, o provimento de fundo, cuja antecipação ela vem provocar..." 61

4. Conclusão.

A exceção de pré-executividade, muito embora não tenha sido

58. Op. cit., p. 66.

59. LACERDA, Galeno, "Limites ao Poder Cautelar Geral e a Concessão de Liminares", op. cit., p. 98.

60. Diz o art. 804, que "É lícito ao juiz conceder liminarmente ou após justificação prévia a medida cautelär-sem ouvir or réu, quando verificar que este, sendo citado, poderá torná-la ineficaz. [...]".

61. MANCUSO, Rodolfo de Camargo, op. cit., pp. 73-74. 
especificamente nomeada pelo Código de Processo Civíl, vem para suprir as deficiências do processo de execução no âmbito da ampla defesa e do contraditório, nos casos em que possa ser determinada de ofício a extinção, ou mesmo a suspensão da ação.

Concluímos que o poder cautelar geral do juiz se expressa, não-somente na concessão de medidas cautelares inominadas previstas no Livro III do CPC - arts. 798 e 799, (em sede, portanto, de ações cautelares) - mas também pelos provimentos cautelares, estes últimos fora do âmbito do processo cautelar. Estes provimentos cautelares serão típicos, quando expressos no CPC, como o caso do art. 793 do CPC e atípicos quando não estiverem previstos expressamente no $\mathrm{CPC}$ e, neste caso, sujeitos à discricionaridade do juiz. Além disso, serão emanados em decisões interlocutórias, à medida que surja, como questão incidental, nestes processos, o risco de lesão de difícil ou impossível reparação a direito da parte, sem que seja necessário esta ajuizar ação cautelar incidental, para proteger este direito, em conformidade com os princípios da economia processual e o da necessidade.

Como este provimento cautelar não possui forma determinada, como vimos anteriormente, pode a parte, por decorrência lógica, requerer em um processo de execução judicial de hipoteca, disciplinado pela Lei n. 5.741/71, provimento cautelar do juiz, em sede de exceçãó de pré-executividade, para que este suspenda a execução até trânsito julgado da ação de revisão contratual de prestações e saldo devedor a que o executado tem direito a ajuizar, inclusive com a efetividade da prestação jurisdicional nela pleiteada.

A necessidade da suspensão cautelar ser requerida por via da exceção de pré-executividade se dá, como vimos, quando os embargos de devedor não possuírem efeito suspensivo (que é o caso notório da execução hipotecária criada pela Lei $n$. $5.741 / 71$ ), a menos que o executado deposite por inteiro o valor da dívida que ensejou esta execução. ${ }^{62}$

Para ilustrar, no sentido de que os embargos de devedor não possuem efeito suspensivo na execução de hipoteca prevista na Lei n. 5.741/71, citamos abaixo decisão do SFH (RESP 133100/PR ; 1 1a Turma do STJ, Rel. Exmo Sr. Min. Demócrito Reinaldo, unânime, DJU de 10/05/1999, p.105):

\section{"PROCESSUAL CIVIL. EMBARGOS À EXECUÇÃO HIPOTECÁRIA. EFEITO SUSPENSIVO (LEI 5.741/7I). \\ No âmbito do processo de execução hipotecária vinculada ao Sistema \\ Financeiro de Habitação, que tem disciplina em legislação específica}

62. Lei 5.741/71, art. 5०: O executado poderá opor embargos no prazo de dez (10) dias contados da penhora e que seräo recebidos com efeito suspensivo desde que alegue e prove:

1 - que depositou por inteiro a importância reclamada na inicial;

II - que resgatou a divida, oferecendo desde logo a prova da quitaşä́o.

Parágrafo único. Os demais fundamentos de embargos, previstos no art. 741 do Código de Processol Civil, näo suspendem a execuçäo. 
(Lei 5.741/7I), os embargos só podem ser recebidos com suspensão da execução: desde que o executado prove que depositou, por inteiro, a importância reclamada na inicial em que pagou a divida, oferecendo, de logo, a prova de quitação. Recurso desprovido. Decisão unânime."

Em nosso entender, ainda, o juiz deve dar este provimento cautelar nos processos de conhecimento, ou de execução, sem constituição formal de processo cautelar incidental, por aplicação do princípio da economia processual e o da necessidade, toda a vez que houver os requisitos do fumus boni iuri e periculum in mora, se a matéria for de possível cognição por ele, bastando para tanto a manifestação das partes, atendendo-se assim ao princípio do contraditório.

Destaca-se, especialmente, o caso da ação de conhecimento, ajuizada anteriormente, em que haja justa controvérsia sobre a existência ou o montante do débito. Neste caso, e especialmente quando houver litigância de má-fé por parte do credor, ao ajuizar ação conexa em outro Foro, é cabível, além da suspensão da execução, a própria extinção do feito, por nulidade, carecedora dos requisitos de liquidez ou certeza.

São Paulo, maio de 2002.

\section{Bibliografia.}

ALMEIDA, Jorge Luiz de. Liminar Cautelar em Procedimento Conum. 1992. Tese (Doutorado em Direito) - Faculdade de Direito, Universidade de São Paulo, São Paulo. Orientador: Prof. Cândido Rangel Dinamarco.

ANDRADE, José Batista de. "Exceção de pré-executividade", Revista Síntese de Direito Civil e Processual Civil. Porto Alegre: Síntese, 2001, ano II, n. 10, mar./ abr., pp. 60-62.

ASSIS, Araken de, Manual do processo de execução, São Paulo: RT, 2000, $6^{\mathrm{a}}$ ed.

BOJUNGA, Luiz Edmundo Appel. "A exceção de pré-executividade", Revista de Processo. São Paulo: RT, 1989, ano 14, n. 55, jul./set., pp.62-70.

CAIS, Cleide Previtalli. "Exceção de pré-executividade em execução fundada em título executivo extrajudicial", Revista Dialética de Direito Tributário. São Paulo: Oliveira Rocha, 1999, n. 43, abril, pp. 22-32.

CORREIA, Marcos Orione Gonçalves. "Aspectos da exceção de préexecutividade no processo civil e sua admissibilidade no processo do trabalho", Revista de direito do trabalho. São Paulo: RT, 2001, ano 27, n. 102, abr./jun., pp. 78-85.

DAL COL, Helder Martinez. "A objeção de não-executividade" Repertório $I O B$ de Jurisprudência. São Paulo: IOB, 2000, $1^{\text {a }}$ quizena de maio, $n^{\circ}$ 9, caderno 3 , pp. 201-195. 

$7^{\mathbf{a}}$ ed.

DINAMARCO, Cândido Rangel. Execução Civil. São Paulo: Malheiros, 2000, $2^{\mathrm{a}}$ ed., pp. 172-173. . Fundamentos do Processo Civil Moderno. São Paulo: RT, 1987,

DUARTE, Walter Antonio Dias, e MELLO NETO, Luis Soares de. "Considerações sobre a execução hipotecária - Penhora de outros bens além do hipotecado - Impossibilidade", Revista de Direito Civil - Imobiliário, Agrário e Empresarial, São Paulo: RT, 1990, ano 14, n. 53 - jul./set. 1990, pp. 90-99.

FANTONI JR:, Neyton. "Exceção de pré-executividade: limites e possibilidades" Revista Síntese de Direito Civil e Processual Civil. Porto Alegre: Síntese, 2000, ano II, n ${ }^{\circ}$ 8, nov./dez., pp. 17-20.

FORNICIARI JR., Clito. "Exceção de pré-executividade", Revista Síntese de Direito Civil e Processual Civil. Porto Alegre: Síntese, 2000, ano I, n. 4, mar./abr., pp. 30-31.

GONÇALVES NETO, Francisco. "Exceção ou objeção de pré-executividade". Revista LTr. São Paulo: LTr, 2000, ano 64, n. 5, maio, pp. 614-617. v. II.

GRECO, Leonardo. O Processo de Execução. Rio de Janeiro: Renovar, 2001,

GRECO FILHO, Vicente. Direito Processual Civil Brasileiro. São Paulo: Saraiva, $1994,8^{\text {a }}$ ed. , v. 3.

HOLANDA, Aurélio Buarque de. Novo dicionário Aurélio da língua portuguesa. Rio de Janeiro: Nova Fronteira, $2^{\mathrm{a}}$ ed, 1986.

JORGE, Flávio Cheim. "O Processo Cautelar e o Poder Geral de Cautela do Juiz". Revista de Processo. Ed. RT, 1997, ano 22, jul./set., n. 87, pp. 186-198.

LACERDA, Galeno. Comentários ao Código de Processo Civil. São Paulo: Forense, 1980, v. VIII, Tomo 7.

"Execução de título extrajudicial e segurança do juízo", Revista Ajuris, n. 23, Porto Alegre: Associação dos Juízes do Rio Grande do Sul, 1981, n. 23. "Limites ao Poder Cautelar Geral e a Concessão de Liminares" Revista Ajuris. Porto Alegre: Assóciação dos Juízes do Rio Grande do Sul, 1993, ano XX, n. 58, jul., 95-104.

LIMA, Alcides de Mendonça. Processo de conhecimento e processo de execução (nova série). Rio de Janeiro: Forense.

MAGALHÃES, Jorge de Miranda. "A Execução e a exceção pré-processual" Revista de direito do Tribunal de Justiça do Estado do Rio de Janeiro. Rio de Janeiro: TJRJ, 1995, n. 25, out./dez., pp. 15-21.

MANCUSO, Rodolfo de Camargo. "A Questão dos limites no Poder Cautelar Geral”, Revista do Tribunal de Contas do Município de São Paulo. São Paulo: 2000, ano II, n. 7, P1 a P96, set., pp. 58-75. 
MILHOMENS, Jônatas. Processo de Execução. Rio de Janeiro: Forense, 1991.

MOLITOR, Deborah de Araújo. "Reflexões sobre a exceção de préexecutividade" Revista da Faculdade de Direito de São Bernardo do Campo. São Bernardo do Campo: Faculdade de Direito de São Bernardo do Campo, 2000, v. 6, tomo I, pp. 49-58.

MOREIRA, Alberto Camiña. Defesa sem embargos do executado. São Paulo: Saraiva, 2000.

MOREIRA, Lenice Silveira. "A exceção de pré-executividade e o juízo de admissibilidade na ação executiva" Repertório $I O B$ de Jurisprudência. São Paulo: IOB, 1999, $2^{\text {a }}$ quizena de fevereiro, n. 4, caderno 3, pp. 102-89.

NETTO, Nelson Rodrigues, "Exceção de pré-executividade" Revista de Processo. São Paulo: RT, 1999, ano 24, n. 95, jul./set., pp. 29-38.

PEREIRA, Tarlei Lemos. "Exceção de pré-executividade" Revista dos Tribunais. São Paulo: RT, 1999, ano 88, v. 760, fevereiro, pp. 767-786.

PINTO, Nelson Luiz. "Medidas Cautelares - Poder Cautelar de Juiz" Revista de Processo. Ed. RT,, 1990, ano 15, jul./set., n. 59, pp. 179-186.

PORTANOVA, Rui. Princípios do Processo Civil. Porto Alegre: Livraria do Advogado, 1995.

SÁ, Rodrigo Cesar Caldas de. "Exceção de pré-executividade e Fazenda Pública: pode alguém ser submetido a processo executivo sem pressupostos ou condições constituição ou desenvolvimento regular?", Revista Dialética de Direito Tributário. São Paulo: Oliveira Rocha, 2000, n. 53, fevereiro, pp. 95-104.

SAMPAIO, Marcus Vinicius de Abreu. O Poder Geral de Cautela do Juiz. São Paulo: RT, 1993.

SANCHES, Sydney. "Poder Cautelar Geral do Juiz" Revista Ajuris. Porto Alegre: Associação dos Juízes do Rio Grande do Sul, 1988, ano XV, n. 44, nov., pp. 58-66.

SANDIM, Emerson. "Medida Cautelar para Suspender Processo de Execução" Revista do Curso de Direito da Universidade Federal de Uberlândia. Uberlândia: 1992, v. 21, n. 1/2, pp. 99-119, dez.

SANTOS, Ernani Fidélis dos. Manual de Direito Processual Civil. São Paulo: Saraiva, 1987, v.3.

SANTOS, Moacyr dos. Primeiras linhas do Direito Processual Civil. São Paulo: Saraiva, 1977, v. II, $3^{\text {a }}$ ed., p. 55.

SILVA, Antônio Carlos Costa e. Da jurisdição executiva e dos pressupostos da execução civil. Rio de Janeiro: Forense, 1980.

SILVA, José Vilaço da. "Exceção de pré-executividade e a execução fiscal" Revista de Estudos Tributários. Porto Alegre: Síntese, 2000, Ano II, n. 11, jan./fev., pp. 11-16. 
THEODORO JR., Humberto. "Contrato de abertura de crédito como título executivo", Revista Forense. Rio de Janeiro: 1996, ano 92, v. 334, abr./jun., pp. 231246.

THEODORO JR:, Humberto. Curso de Direito Processual Civil. Rio de Janeiro: Forense, 1999, $26^{\mathrm{a}}$ ed., v. II.

THEODORO JR., Humberto. Processo de Execução. São Paulo: LEUD, 1975, p. 102.

TUCCI, Rogério Lauria, "Execução - Cédula de Crédito Industria)" Revista dos Tribunais, São Paulo: RT, 1989, ano 78, v. 642, pp. 26-32.

VIANA, Rui Geraldo Camargo, "O direito à moradia", Revista da Faculdade de Direito. São Paulo: Faculdade de Direito da Universidade de São Paulo, 2000, v. 95, jan./dez., pp. 453-552.

VILLAR, Willard de Castro, Processo de Execução, São Paulo: RT, 1975.

ZAVASCKI, Teori Albino, Título Executivo e Liquidação. São Paulo: RT, 1999. 